University of Nebraska - Lincoln

DigitalCommons@University of Nebraska - Lincoln

Faculty Publications in Food Science and Technology

Food Science and Technology Department

2011

Nutritional and anti-nutritional compositions of defatted Nebraska hybrid hazelnut meal

\author{
Yixiang $\mathrm{Xu}$ \\ Virginia State University, yixu@vsu.edu \\ Milford Hanna \\ University of Nebraska-Lincoln, mhanna1@unl.edu
}

Follow this and additional works at: https://digitalcommons.unl.edu/foodsciefacpub

Part of the Food Science Commons

Xu, Yixiang and Hanna, Milford, "Nutritional and anti-nutritional compositions of defatted Nebraska hybrid hazelnut meal" (2011). Faculty Publications in Food Science and Technology. 95.

https://digitalcommons.unl.edu/foodsciefacpub/95

This Article is brought to you for free and open access by the Food Science and Technology Department at DigitalCommons@University of Nebraska - Lincoln. It has been accepted for inclusion in Faculty Publications in Food Science and Technology by an authorized administrator of DigitalCommons@University of Nebraska - Lincoln. 


\title{
Original article \\ Nutritional and anti-nutritional compositions of defatted Nebraska hybrid hazelnut meal
}

\author{
Yixiang $\mathrm{Xu}^{1} \&$ Milford A. Hanna ${ }^{2} *$ \\ 1 Agricultural Research Station, Virginia State University, Petersburg, VA 23806, USA \\ 2 Industrial Agricultural Products Center, University of Nebraska, Lincoln, NE 68583, USA
}

(Received 8 February 2011; Accepted in revised form 14 June 2011)

Summary Defatted meal of hybrid hazelnuts may have potential food and value-added industrial applications. The proximate composition, mineral elements, amino acid profile and anti-nutritional factors (total phenolics, tannins, condensed tannins and phytates) of defatted meals of ten Nebraska hybrid hazelnut genotypes were investigated. Excluding the amino acid profile, the nutritional and anti-nutritional compositions of the meals differed significantly, with high protein, carbohydrate, neutral and acid detergent fibre concentrations and energy value. Mineral concentrations were higher than those previously reported. $\mathrm{K}$ was the most abundant mineral element, followed by $\mathrm{P}, \mathrm{Ca}$ and $\mathrm{Mg}$. Seven essential amino acids accounted for approximately $27.8 \%$ of the total amino acid contents. Tryptophan was not detected. All essential amino acid contents were significantly lower than the reference levels recommended for human and animal consumption. The high levels of anti-nutritional factors, such as total phenolics, tannins, condensed tannins and phytate in the meals, could reduce protein and mineral bioavailability.

Keywords Amino acid, anti-nutritional factors, defatted meal, hybrid hazelnuts, mineral elements, proximate composition.

\section{Introduction}

Hazelnuts (Corylus spp.), also known as filberts, are an important commercial crop in many countries. The United States is the third largest hazelnut producer in the world, behind Turkey and Italy. In the USA, commercial hazelnut production occurs largely in Oregon, which produces three per cent of the world's hazelnuts. Currently, all commercial hazelnut cultivars come from the European hazelnut (Corylus avellana) because they produce nuts of higher quality, larger size and with thinner shells. However, the European hazelnut cannot tolerate the harsh winters of the Upper Midwest, nor are they resistant to eastern filbert blight (a native disease of hazelnuts in the eastern USA that is uniformly fatal to the European hazelnut). On the other hand, native American species are cold tolerance and disease resistance, but the nuts produced are smaller and, therefore, of less commercial value. Commercialquality hybrid hazelnut shrub cultivars, which combine the superior qualities of the European hazelnut with disease resistance and cold hardiness of the American species, show great potential as an oilseed crop in the Upper Midwest (Hammond, 2006). Recently, hybrid

\footnotetext{
*Correspondent: Fax: +1 402 4726338;

e-mail: mhanna1@unl.edu
}

hazelnuts have emerged as a promising oilseed crop in Nebraska requiring relatively low inputs and marginal soils. A 9 ac hybrid hazelnut planting at Arbor Day Farm in Nebraska City, NE, USA was established in 1996 and currently is one of the largest plantings of hybrid hazelnuts in the east of the Rocky Mountains. There are 5200 genetically distinct hybrid hazelnut shrubs grown from open-pollinated seedlings derived from a breeding programme at Badgersett Research Corporation, Canton, MN, USA. These commercialquality hybrid hazelnut shrub cultivars combine the superior qualities (larger size and thinner shells) of the European hazelnut with disease (eastern filbert blight) resistance and cold hardiness of the American species.

Evaluation of the top 25 producing Nebraska hybrid hazelnuts suggested that a significant opportunity existed for developing hazelnuts as an economically feasible, sustainable and environmentally friendly oilseed crop for food, feed and industrial applications ( $\mathrm{Xu}$ et al., 2007). Hybrid hazelnuts have high and valuable quantities of nutrients in the form of oil, protein, fibre and minerals (Xu \& Hanna, 2010a). Their unique fatty acid profile and physicochemical properties, together with being rich in bioactive nutrients (phytosterol and tocopherol), make hazelnut oil ideal for food and industrial applications (Xu \& Hanna, 2010b). Further, it is of great interest to identify uses for the defatted 
meal, which is a by-product of oil extraction. The high nutritive value of the defatted hazelnut meal may offer opportunities for uses as human food and animal feed supplements. Defatted hazelnut meals have been utilised as a substitute for the fish and soybean meals for poultry diet and fish feeds (Yalcin et al., 2005; Buyukcapar \& Kamalak, 2007; Emre et al., 2008). However, like most plant protein sources, defatted hazelnut meal could contain anti-nutritional factors, such as phenolics, tannins, condensed tannins and phytates, which have been shown to negatively affect feed intake, body weight gain and feed conversion (Erener et al., 2009). Antinutritional factors generally refer to naturally occurring allelochemical substances, or their metabolites, which interfere with protein and mineral utilisation and affect the health and production of animals (Francis et al., 2001). Therefore, the objective of this study is to provide information on nutritional and anti-nutritional compositions of the Nebraska hybrid hazelnut meal after oil extraction for animal feed applications.

\section{Materials and methods}

\section{Materials}

Hybrid hazelnuts were hand harvested in the fall of 2008 from Arbor Day Farm, Nebraska City, NE. The top 10 producing genotypes from a total of 5199 hybrid hazelnuts planted from 99 different material lines were selected for further processing. The top producing genotypes were identified by establishing four transects, randomly located perpendicular across all rows and ranged in length from approximately 27 to $165 \mathrm{~m}$ in the planting to provide an estimated average yield of the plantation. Nuts were mechanically de-hulled, sorted by size and cracked using mechanical crackers. Kernels were ground into powder using a coffee grinder and dried for $8 \mathrm{~h}$ prior to hexane extraction of the oil. The remaining defatted meals were used to determine selected nutritional and anti-nutritional compositions.

\section{Proximate analyses and fibre fractions}

Hazelnut meals were dried at $60{ }^{\circ} \mathrm{C}$ for $24 \mathrm{~h}$ prior to all analyses. Analyses of crude protein, oil and ash were performed using the methods as described by Association of Official Analytical Chemists (AOAC, 1990). Crude protein content was measured by combustion method (AOAC 990.03) using an FP-528 Nitrogen/Protein Analyzer with DSP Control (Leco Corp. St. Joseph, MI, USA). The $\mathrm{N}$ in the samples was converted into nitric oxide by combustion, which further was reduced to molecular nitrogen. Nitrogen gas was measured with a thermal conductivity detector, using helium as a reference. Crude protein content was calculated by multiplying nitrogen concentration by a conversion factor of 6.25. The oil content was measured using a Soxhlet apparatus (AOAC method 948.22). The oil was extracted from the dried, ground samples using $50 \mathrm{~mL}$ of hexane for $8 \mathrm{~h}$. After the extraction, the hexane was evaporated and the collection cups containing the extracted oil were placed in a vacuum oven at $95^{\circ} \mathrm{C}$ for $1 \mathrm{~h}$ to remove all traces of hexane. The cups were cooled and weighed. Ash content was determined by a burning method (AOAC method 950.49). The dried sample was weighed into a porcelain crucible, placed in muffle furnace preheated to $600{ }^{\circ} \mathrm{C}$ and held at that temperature for $2 \mathrm{~h}$. The crucible was then transferred into desiccators, cooled and weighed. Carbohydrate content was determined by subtracting the total percentage of other components from 100. Neutral detergent fibre and acid detergent fibre of the meals were analysed using reflux methods (Van Soest, 1963; Van Soest et al., 1991). Defatted samples were mixed with either neutral detergent solution or acid detergent solution in Berzelius beakers and were boiled at a constant steady reflux for $60 \mathrm{~min}$. The mixtures were then filtered through preweighed Whatman 541 filters. The filters and residues were dried at $100{ }^{\circ} \mathrm{C}$ for $12 \mathrm{~h}$ and then cooled and weighed. Energy values were measured using a bomb calorimetry (model 1108 Adiabatic oxygen chamber (bomb) and the 1241 calorimeter; Parr Instrument Company, Moline, IL, USA). Energy values of the samples were determined based on the change in temperature of the calorimeter system, the heat capacity of the calorimeter system and the mass ( $\mathrm{g}$ ) of sample used.

\section{Mineral compositions}

The mineral elements, namely $\mathrm{Ca}, \mathrm{Cu}, \mathrm{Fe}, \mathrm{Mg}, \mathrm{Mn}, \mathrm{P}$, $\mathrm{K}, \mathrm{Na}$, Se and $\mathrm{Zn}$, were measured using a $\mathrm{GV}$ Instrument Platform XS inductively coupled plasma mass spectrometer (ICP-MS) (Manchester, UK). Dried samples $(0.25 \mathrm{~g})$ were digested in $10 \mathrm{~mL}$ of concentrated $\mathrm{HNO}_{3}$ and $0.05 \mathrm{~mL} \mathrm{HF}$ in $50 \mathrm{~mL}$ Teflon vessels using a microwave digestion system at $170{ }^{\circ} \mathrm{C}$ for $30 \mathrm{~min}$ with $1600 \mathrm{~W}$. The samples were then cooled, filtered through $0.45-\mu \mathrm{m}$ glass fibre filter paper and diluted with deionised water to $50 \mathrm{~mL}$ for analyses for all elements except Se. For Se, a $5 \mathrm{~mL}$ volume of digest was transferred to a digestion tube and $5 \mathrm{~mL}$ of concentrated $\mathrm{HCl}$ (Trace Metal Grade, Fischer Scientific, Pittsburgh, PA, USA) was added. The contents were heated in a block heater for about $10 \mathrm{~min}$ at $100{ }^{\circ} \mathrm{C}$ for $1 \mathrm{~h}$, cooled to room temperature and then diluted and analysed on a CETAC HGX-200 hydride generator (Omaha, Nebraska) and ICP-MS.

\section{Amino acid profile}

The amino acid profiles of hybrid hazelnut meals were determined using ion-exchange chromatography. Hazel- 
nut meals were hydrolysed in $6 \mathrm{M} \mathrm{HCl}$ for $20 \mathrm{~h}$ at $110{ }^{\circ} \mathrm{C}$. For determining sulphur-containing amino acids (cysteine and methionine), the samples were first oxidised with performic acid prior to hydrolysis with $6 \mathrm{~m} \mathrm{HCl}$. The hydrolysed samples were filtered quantitatively into $200-\mathrm{mL}$ volumetric flasks and were diluted to volume with deionised water. Sample solutions $(15 \mathrm{~mL})$ and $2.5 \mathrm{~mL}$ of norleucine internal standard $\left(2.5 \mu \mathrm{mols} \mathrm{mL}^{-1}\right)$ were pipetted into a $250-\mathrm{mL}$ boiling flask and evaporated to dryness in a Buchi vacuum rotary evaporator (R114; BUCHI Corporation, New Castle, DE, USA). Samples then were transferred to $50-\mathrm{mL}$ volumetric flasks and diluted to volume with lithium diluents and then were filtered through $13 \mathrm{~mm}$ Swinney and $0.2 \mu \mathrm{m}$ Gelman membrane filters prior to analysis. The amino acids were separated, identified and quantified using a Waters HPLC system (Waters Corporation, Milford, MA, USA) consisting an autosampler, a $3 \times 250 \mathrm{~mm}$ stainless steel and $10 \mu \mathrm{m}$ cationexchange resin Pickering $\mathrm{Li}^{+}$column at $42{ }^{\circ} \mathrm{C}$, and Waters 474 fluorescence detector. The excitation wavelength and emission wavelength were $330 \mathrm{~nm}$ and $450 \mathrm{~nm}$, respectively. Amino acids were measured by postcolumn derivitisation with ortho-phthalaldehyde. An amino acid standard was used for identification, while norleucine was used as an internal standard for qualification. The mobile phase was gradient elution buffers, namely Li275 (Lithium eluant, pH 2.75), Li750 (Lithium eluant, pH 7.50) and RG003 (Lithium column regenerant) (Pickering Laboratories, Inc. Mountain View, CA, USA), at a flow rate of $0.3 \mathrm{~mL} \mathrm{~min}^{-1}$.

\section{Anti-nutritional compositions}

The levels of potential anti-nutritional factors (phenolics and phytate) in the defatted meals from the 10 hybrid hazelnut cultivars were measured. Total phenolics, tannins and condensed tannins were extracted according to the method of FAO/IAEA (2000). Dried meal $(200 \mathrm{mg}$ ) was mixed with $10 \mathrm{~mL}$ of aqueous acetone $(70 \%)$ and subjected to ultrasonic treatment for $20 \mathrm{~min}$ at room temperature, followed by centrifugation for $10 \mathrm{~min}$ at approximately $3000 \mathrm{~g}$ at $4{ }^{\circ} \mathrm{C}$. The supernatant was collected and kept on ice. The pellet was re-extracted with two $5 \mathrm{~mL}$ aliquots each of $70 \%$ aqueous acetone as described earlier, and the supernatants were pooled. Total phenolics and tannins concentrations were determined by the Folin-Ciocalteu method as described by Makkar et al. (1993). For total phenolics, the extract was mixed with Folin-Ciocalteu reagent and $20 \%$ sodium carbonate solution. After $40 \mathrm{~min}$, the absorbance was recorded at $725 \mathrm{~nm}$ using a Shimadzu UV-1800 spectrophotometer (Columbia, MD, USA). Tannin content was different between total phenolics and simple phenolics. Insoluble matrix, polyvinyl polypyrrolidone (PVPP), was used to bind tannin- phenolics. Simple phenolics were measured by the Folin-Ciocalteu method, as mentioned earlier. Both total phenolics and tannins were expressed as tannic acid (TA) equivalent on a dry matter basis. Determinations of condensed tannins were performed according to the method by Porter et al. (1986). The tannin extract was diluted with $70 \%$ acetone, followed by addition of butanol- $\mathrm{HCl}$ and ferric reagents. The tubes were vortexed and held in a water bath $\left(100{ }^{\circ} \mathrm{C}\right)$ for $60 \mathrm{~min}$. After that, they were cooled, and absorbance was recorded at $550 \mathrm{~nm}$. Condensed tannins were expressed as leucocyanidin equivalent ( $\%$ in dry matter).

Phytate was analysed using a rapid colorimetric procedure (Latta \& Eskin,1980). Phytate first was extracted with $\mathrm{HCl}$, and then the extract was passed through an AG1-X8 anion-exchange resin to remove inorganic phosphorus and other interfering compounds. Phytate content was measured based on the reaction between ferric ion and sulfosalicylic acid in the Wade reagent. Absorbance was read at $500 \mathrm{~nm}$.

\section{Statistics analyses}

Three replications were used to obtain average values and standard deviations for all tests. All results were analysed with SAS version 9.2 statistical software (SAS Institute Inc., Cary, NC, USA). Duncan's multiple range test was used to evaluate the difference in nutritional and anti-nutritional compositions. Probability $(P)<0.05$ indicates significance, while $P>0.05$ indicates nonsignificance.

\section{Results and discussion}

\section{Proximate compositions and fibre fractions}

Proximate compositions, in terms of oil, protein, ash, total carbohydrate and energy value, and fibre fractions including neutral detergent fibre (NDF) and acid detergent fibre (ADF) of 10 defatted hybrid hazelnut meals are presented in Table 1. All data are reported on a dry basis. Oil content $(3.52 \%)$ of defatted meal was significantly $(P<0.05)$ lower than that of pristine meal $(55.1 \%)$. Protein was the predominate component in the defatted hazelnut meals with an average content of $48.2 \%$ and ranging from $41.3 \%$ to $54.4 \%$. This was approximately threefold higher than their pristine counterparts $(18.0 \%)$ and was similar to the protein content in soybean meal (Kaushik et al., 1995; Xu \& Hanna, 2010a). The high protein content made the defatted hazelnut meal a good supplement for lowprotein cereal flours for human consumption and livestock feed. Further, three of the ten genotypes tested (10-57, 18-12 and 29-142) had protein contents over $50 \%$, and the protein contents in two of them (10-57 and 29-142) were significantly $(P<0.05)$ higher than the 
Table 1 Proximate composition of defatted hybrid hazelnut meals (dry basis)

\begin{tabular}{|c|c|c|c|c|c|c|c|}
\hline Genotype & Crude oil (\%) & $\begin{array}{l}\text { Crude } \\
\text { protein (\%) }\end{array}$ & Ash (\%) & $\begin{array}{l}\text { Total } \\
\text { carbohydrate (\%) }\end{array}$ & $\begin{array}{l}\text { Energy } \\
\text { value }\left(\mathrm{Cal} \mathrm{g}^{-1}\right)\end{array}$ & NDF (\%) & ADF (\%) \\
\hline 20-January & $3.26 \pm 0.15^{c}$ & $41.3 \pm 0.55^{h}$ & $8.02 \pm 0.51^{a b}$ & $47.5 \pm 0.57^{a}$ & $4349 \pm 0.1^{c}$ & $24.9 \pm 0.89^{c d e}$ & $17.3 \pm 0.67^{a}$ \\
\hline October-50 & $4.34 \pm 0.02^{a}$ & $49.9 \pm 0.97^{b c}$ & $7.81 \pm 0.44^{a b}$ & $37.9 \pm 0.26^{e f}$ & $4468 \pm 9.2^{a}$ & $26.1 \pm 0.33^{b c d}$ & $17.0 \pm 1.17^{a}$ \\
\hline October-57 & $3.64 \pm 0.41^{a b c}$ & $54.4 \pm 0.32^{a}$ & $7.03 \pm 0.45^{b}$ & $34.9 \pm 0.27^{g}$ & $4390 \pm 13.4^{b}$ & $21.9 \pm 1.05^{e}$ & $13.5 \pm 0.30^{b c}$ \\
\hline November-54 & $4.21 \pm 0.05^{a b}$ & $48.1 \pm 0.41^{d e}$ & $7.57 \pm 0.30^{a b}$ & $40.1 \pm 0.30^{d}$ & $4341 \pm 13.4^{c}$ & $27.8 \pm 1.84^{b c}$ & $16.9 \pm 0.37^{a}$ \\
\hline $13-34$ & $3.40 \pm 0.32^{b c}$ & $46.7 \pm 0.94^{e f}$ & $8.62 \pm 0.14^{a b}$ & $42.2 \pm 0.01^{c}$ & $4243 \pm 12.7^{e}$ & $28.7 \pm 1.84^{b}$ & $10.4 \pm 0.11^{d}$ \\
\hline $16-177$ & $4.08 \pm 0.31^{a b c}$ & $44.6 \pm 0.87^{g}$ & $8.46 \pm 1.19^{a b}$ & $43.0 \pm 0.27^{b}$ & $4367 \pm 27.6^{b c}$ & $23.4 \pm 1.56^{d e}$ & $14.3 \pm 0.49^{b}$ \\
\hline $18-12$ & $3.87 \pm 0.35^{a b c}$ & $50.6 \pm 0.21^{b}$ & $7.11 \pm 1.10^{a b}$ & $38.5 \pm 0.27^{e}$ & $4474 \pm 23.3^{a}$ & $22.0 \pm 0.99^{e}$ & $14.1 \pm 0.03^{b}$ \\
\hline $25-60$ & $3.89 \pm 0.09^{a b c}$ & $45.3 \pm 0.54^{g f}$ & $8.64 \pm 0.50^{a}$ & $42.2 \pm 0.04^{b c}$ & $4372 \pm 16.3^{b c}$ & $27.5 \pm 1.46^{b c}$ & $17.4 \pm 1.14^{a}$ \\
\hline 28-105 & $1.93 \pm 0.02^{d}$ & $48.7 \pm 1.05^{c d}$ & $7.92 \pm 0.58^{a b}$ & $41.5 \pm 0.24^{c d}$ & $4302 \pm 0.7^{d}$ & $23.1 \pm 1.39^{d e}$ & $12.1 \pm 1.22^{c}$ \\
\hline $29-142$ & $2.55 \pm 0.29^{d}$ & $52.9 \pm 0.85^{a}$ & $7.50 \pm 0.86^{a b}$ & $37.0 \pm 0.14^{f}$ & $4390 \pm 24.1^{b}$ & $33.9 \pm 0.41^{a}$ & $13.5 \pm 0.30^{b c}$ \\
\hline Mean & $3.52 \pm 0.02$ & $48.2 \pm 0.42$ & $7.86 \pm 0.45$ & $40.4 \pm 0.03$ & $4369 \pm 14.1$ & $25.9 \pm 1.18$ & $14.7 \pm 0.58$ \\
\hline Range & $1.93-4.34$ & $41.3-54.4$ & $7.03-8.64$ & $34.9-47.5$ & $4243-4474$ & $21.9-33.9$ & $10.4-17.4$ \\
\hline
\end{tabular}

NDF, neutral detergent fibre; ADF, acid detergent fibre.

Data are expressed as mean of three replications.

Means followed by the same letter within a column indicate no significant $(P>0.05)$ difference by Ducan's multiple range test.

others. Carbohydrate was the second major component in the defatted meals and had an average content of $40.4 \%$ and ranged from $34.9 \%$ to $47.5 \%$, followed by ash (average value of $7.86 \%$ and range of $7.03 \%$ to $8.64 \%$ ). Nebraska hybrid hazelnut-defatted meals had comparable protein, oil and ash contents with their Turkish counterparts, which reportedly are $44.8 \%$ protein, $3.36 \%$ oil and $6.68 \%$ ash, respectively (Doğan \& Erdem, 2010).Further, Nebraska hazelnut-defatted meals had an average energy value of $4.36 \mathrm{kcal} \mathrm{g}^{-1}$, ranging from 4.24 to $4.47 \mathrm{kcal} \mathrm{g}^{-1}$. The high protein and carbohydrate contents contributed to the high energy value of the meals, making them an excellent energy source for animals.

Neutral detergent fibre and acid detergent fibre are good indicators of fibre contents and are the most common measures of fibre used for animal feed analyses to evaluate the fibrosity and energy value. The NDF content of the Nebraska hazelnut meal ranged from $21.9 \%$ to $33.9 \%$, while the ADF content ranged between $10.4 \%$ and $17.4 \%$. Bonvehi \& Coll (1993) studied NDF and ADF contents of six Spanish varieties of Tarragona hazelnuts. NDF and ADF levels in their meals ranged from 7.77 to $10.95 \%$ and 5.18 to $7.30 \%$, respectively, which were almost two times lower than those in our meals. The value of forage as animal feed is greatly influenced by NDF and ADF contents. The higher NDF and ADF revealed that more energy would be available to the ruminant animals (Belewu et al., 2008).

\section{Macro- and micro-essential mineral elements}

Table 2 shows concentrations of the different macro and micromineral elements in the Nebraska hybrid hazelnut- defatted meals. $\mathrm{K}$ was the most abundant mineral element, followed by $\mathrm{P}, \mathrm{Ca}, \mathrm{Mg}, \mathrm{Na}, \mathrm{Mn}, \mathrm{Fe}, \mathrm{Cu}, \mathrm{Zn}$ and Se. Mineral concentrations in our meals were higher than those reported for Turkish varieties (Köksal et al., 2006; and Alasalvar et al., 2009), owing to defatting processing involved in our samples. However, the relative concentrations of the mineral elements in our meals and in Turkish meals were similar. The effect of genotypes on mineral contents was significant $(P<0.05)$ : $\mathrm{Ca}, \mathrm{Mg}, \mathrm{Na}$ and $\mathrm{Cu}$ were highest in genotype 25-60, K, P and Se were highest in genotype 28-105, Fe and $\mathrm{Mn}$ were highest in genotype 29-142 and $\mathrm{Zn}$ was highest in genotype 18-12.

Macro and micromineral elements play crucial roles in cell growth and metabolism and therefore are vital to overall mental and physical well-being (Dini et al., 2005). High $\mathrm{Ca}$ and $\mathrm{P}$ contents in the nut meals made them an attractive source for $\mathrm{Ca}$ and $\mathrm{P}$ supplementations. In addition, the nut meals had a mineral profile of high $\mathrm{Ca}, \mathrm{Mg}$ and $\mathrm{K}$ levels associated with low amounts of $\mathrm{Na}$, which was the most beneficial for overall good health and diabetes and coronary heart disease prevention (Segura et al., 2006).

As far as essential micro-elements, they are needed only in trace amounts but are essential to a vast array of body processes. Our nut meals also contained higher $\mathrm{Cu}$, $\mathrm{Fe}, \mathrm{Mn}$ contents but lower Se and $\mathrm{Zn}$ levels than those in Turkish varieties, as reported by Köksal et al. (2006) and Simsek \& Aykut (2007). Nebraska defatted meal served as excellent sources of $\mathrm{Mn}, \mathrm{Fe}, \mathrm{Cu}$ and $\mathrm{Se}$.

\section{Amino acid profile}

The preliminary findings indicated that the effect of genotypes on amino acid profile was not significant 


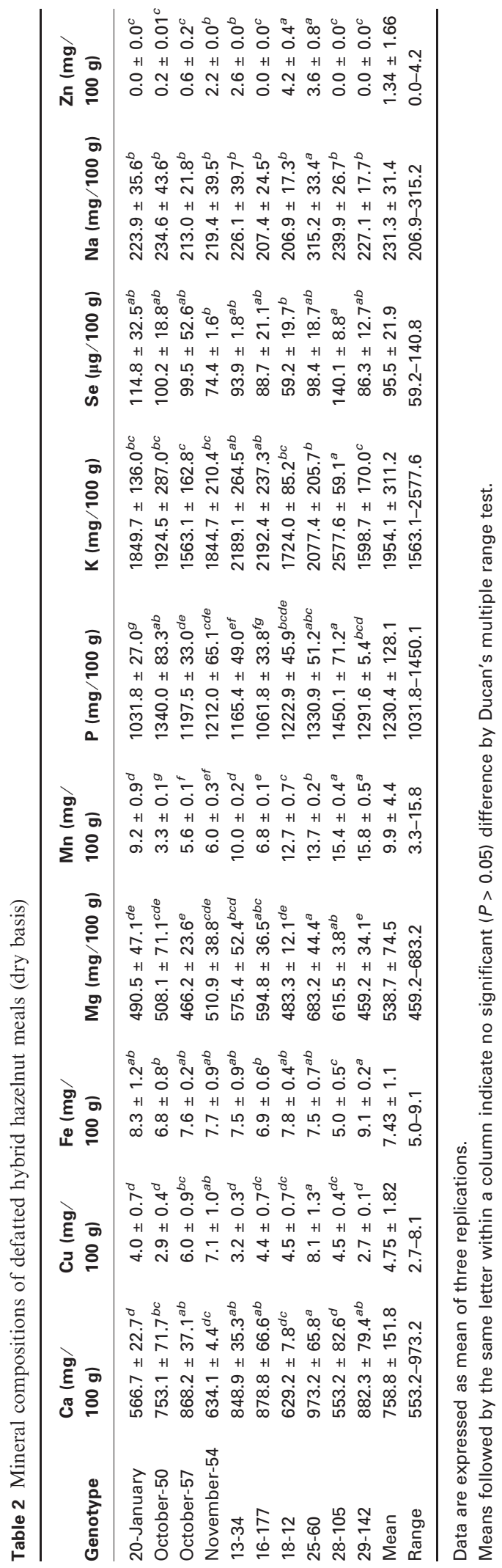

$(P>0.05)$. Table 3 presents amino acid profile of a representative Nebraska hybrid genotype (16-177) defatted meal compared with those from Turkish varieties (Emre et al., 2008) and those from defatted soybean meal (Shiau et al., 1990), because defatted soybean meal is the most common and stable supply for animal feed (Shiau et al., 1990; Kikuchi, 1999; Opapeju et al., 2006). Sixteen amino acids were identified in our meals. Total amino acid contents were $62.5 / 100 \mathrm{~g}$ crude protein. Of the 16 amino acids, seven amino acids (isoleucine, leucine, lysine, methionine, phenylalanine, threonine and valine) were essential amino acids and accounted for $27.8 \%$ of the total amino acid content. The dominant essential amino acid was leucine (4.56/ $100 \mathrm{~g}$ protein), followed by phenylalanine $(2.92 / 100 \mathrm{~g})$, valine $(2.71 / 100 \mathrm{~g})$, isoleucine $(2.15 / 100 \mathrm{~g})$, lysine $(2.06 / 100 \mathrm{~g})$, threonine $(1.94 / 100 \mathrm{~g})$ and methionine $(0.97 / 100 \mathrm{~g})$. However, another important essential amino acid, tryptophan, was not detected in our meal. In addition, all other essential amino acid contents were significantly lower than the reference levels recommended by WHO/FAO and required level of European sea bass (Emre et al., 2008). On the other hand, the nonessential amino acids represented approximately $72.2 \%$ of total amino acid contents. Glutamic acid presented the highest content (15.6/100 g protein), followed by arginine (8.37/100 g protein) and aspartic acid (6.87/100 g protein).

Except for cystine, glutamic acid and methionine, all other amino acids in our hazelnut meals were significant by $(P<0.05)$ lower than their Turkish counterparts studied by Emre et al. (2008). Further, most amino acid levels in our hazelnut meals were significantly $(P<0.05)$ lower compared with those in defatted soybean meal with exceptions of serine, threonine and tyrosine. Our hazelnut meal even had higher serine content than soybean meal, while there was no significant $(P>0.05)$ difference for threonine and tyrosine levels. Based on these analyses, the Nebraska hybrid hazelnut meals contain incomplete proteins, and, therefore, are not a good single protein source.

\section{Anti-nutritional factors}

Although our analyses suggested that hazelnut meal had high nutritional value, the presence of high concentrations of certain anti-nutritional factors limits their utilisation and palatability. Therefore, the evaluation of anti-nutritional factors in the defatted meal is necessary from a nutritional point of view. The levels of several anti-nutritional factors, such as total phenolics, tannins, condensed tannins and phytates, in 10 Nebraska hybrid hazelnut-defatted meals are tabulated in Table 4. Nebraska hybrid hazelnut-defatted meals had an average total phenolics of $10.7 \mathrm{mg} \mathrm{TA} \mathrm{g}^{-1}$, tannins of $7.53 \mathrm{mg} \mathrm{TA} \mathrm{g}^{-1}$ and condensed tannins of 
Table 3 Amino acid profile of one representative hybrid hazelnut (genotype 16-177) defatted meal compared with that from Turkish varieties and from defatted soybean meal

\begin{tabular}{|c|c|c|c|c|c|}
\hline Amino acid & $\begin{array}{l}\text { Nebraska } \\
\text { hazelnut-defatted } \\
\text { meal }(\mathrm{g} / 100 \mathrm{~g} \\
\text { protein) }\end{array}$ & $\begin{array}{l}\text { Turkish } \\
\text { defatted } \\
\text { meal* }(\mathrm{g} / 100 \mathrm{~g} \\
\text { protein) }\end{array}$ & $\begin{array}{l}\text { Defatted } \\
\text { soybean } \\
\text { meal }^{\dagger}(\mathrm{g} / 100 \mathrm{~g} \\
\text { protein) }\end{array}$ & $\begin{array}{l}\mathrm{FAO} / \mathrm{WHO} \\
(\mathrm{g} / \mathbf{1 0 0} \\
\text { protein) }\end{array}$ & $\begin{array}{l}\text { Requirement } \\
\text { by European } \\
\text { sea bass* } \\
\text { (g/100 g protein) }\end{array}$ \\
\hline Alanine & $3.10 \pm 0.06^{b}$ & $5.51^{a}$ & $5.93^{a}$ & & \\
\hline Arginine & $8.37 \pm 0.10^{b}$ & $10.6^{a}$ & $7.08^{c}$ & & 4.1 \\
\hline Aspartic acid & $6.87 \pm 0.10^{c}$ & $16.0^{a}$ & $12.6^{b}$ & & \\
\hline Cystine & $1.39 \pm 0.01^{a}$ & $1.54^{a}$ & - & & \\
\hline Glutamic acid & $15.6 \pm 0.39^{b}$ & $15.9^{b}$ & $22.3^{a}$ & & \\
\hline Glycine & $2.99 \pm 0.11^{c}$ & $5.52^{b}$ & $5.77^{a}$ & & \\
\hline Histidine & $1.69 \pm 0.01^{c}$ & $2.10^{b}$ & $2.58^{a}$ & 1.9 & \\
\hline Isoleucine $e^{\S}$ & $2.15 \pm 0.04^{c}$ & $3.95^{b}$ & $5.26^{a}$ & 2.8 & \\
\hline Leucine $^{\S}$ & $4.56 \pm 0.15^{b}$ & $9.11^{a}$ & $8.93^{a}$ & 6.6 & \\
\hline Lysine ${ }^{\S}$ & $2.06 \pm 0.01^{c}$ & $3.90^{b}$ & $5.77^{a}$ & 5.8 & 4.8 \\
\hline Methionine ${ }^{\xi}$ & $0.97 \pm 0.01^{b}$ & $1.04^{b}$ & $1.55^{a}$ & & \\
\hline Phenylalanine $^{\S}$ & $2.92 \pm 0.01^{b}$ & $5.99^{a}$ & $5.19^{a}$ & & \\
\hline Serine & $3.17 \pm 0.11^{b}$ & $4.21^{a}$ & $1.28^{c}$ & & \\
\hline Threonine $^{\mathcal{\xi}}$ & $1.96 \pm 0.11^{b}$ & $3.75^{a}$ & $2.26^{b}$ & & 2.6 \\
\hline Tryptophan $\$$ & - & - & - & 1.1 & \\
\hline Tyrosine & $1.90 \pm 0.01^{b}$ & $4.13^{a}$ & $1.72^{b}$ & 3.4 & \\
\hline Valine ${ }^{\S}$ & $2.71 \pm 0.08^{c}$ & $5.26^{b}$ & $5.85^{a}$ & 3.5 & \\
\hline Total essential amino acids & 17.4 & 33 & 34.8 & & \\
\hline Total amino acids & 62.5 & 98.5 & 94.1 & & \\
\hline
\end{tabular}

-, indicated not detected.

Data are expressed as mean of three chromatographic injections. Mean \pm SD followed by the same letter within a row and same unit indicate no significant $(P>0.05)$ difference by Ducan's multiple range test

*Source: Emre et al. (2008).

${ }^{\dagger}$ Source: Shiau et al. (1990).

\$Source: FAO/WHO/UNU (1985).

${ }^{\S}$ Essential amino acids.

$0.64 \%$ leucocyanidin equivalent. The effects of the genotype on the phenolic matters were significant $(P<0.05)$. Genotypes 1-20, 16-177 and 29-142 had the highest concentrations of total phenolic, tannins and condensed tannins among the 10 genotypes tested, whereas the lowest levels of total phenolics $(8.71 \mathrm{mg}$ $\mathrm{TA} \mathrm{g}^{-1}$ ), tannins (5.56 $\mathrm{mg} \mathrm{TA} \mathrm{g}^{-1}$ ) and condensed tannins of $0.25 \%$ leucocyanidin equivalent were found in genotype 10-57. The total phenolic content in our hazelnut meal was comparable with that $\left(11.2 \mathrm{mg} \mathrm{g}^{-1}\right)$ of extracted soybean meal (Chivandi et al., 2005) but significantly higher than that $\left(0.125 \mathrm{mg} \mathrm{g}^{-1}\right)$ of Turkish hazelnut-defatted meal (Erener et al., 2009). Tannin content in our meals also was significantly $(P<0.05)$ higher than their Turkish counterpart (Erener et al., 2009).

Tannins are known to be a major cause of the astringency experienced when they were tasted in their unprocessed forms (Enujiugha \& Ayodele-Oni, 2003). More importantly, tannins can form insoluble complexes with protein, thereby interfering with protein bioavailability and reducing the utilisation of energy, and also may inhibit the activities of digestive enzymes
(Siddhuraju et al., 1995; Enujiugha, 2003). Erener et al. (2009) found that diet consumption and body weight gain decreased when animals were fed diets containing tannins and phenolics. As most phenolics and tannins are water soluble, soaking and thermal processing, such as cooking, toasting and extrusion, effectively reduces their levels (Enujiugha, 2003; Mukhopadhyay et al., 2007). It is worthy of note that although phenolics and tannins have a negative effect on utilisations of energy and nutrients, they currently are all considered to be health-promoting factors at low concentrations (Siddhuraju et al., 2001).

Phytate was another anti-nutritional factor in our hazelnut meals, and genotype had a significant $(P<0.05)$ effect on its level. The phytate contents ranged from 18.5 to $33.0 \mathrm{mg} \mathrm{g}^{-1}$, with an average concentration of $26.4 \mathrm{mg} \mathrm{g}^{-1}$, which was higher than that $(10 \mathrm{mg} / 100 \mathrm{~g})$ of Spanish hazelnuts reported by Prieto et al. (2010). A high phytate content could significantly reduce the overall bioavailability of certain essential minerals including $\mathrm{Ca}, \mathrm{Mg}, \mathrm{Fe}$ and $\mathrm{Zn}$ (Enujiugha \& Ayodele-Oni, 2003). This is attributable to the ability of phytate to chelate these mineral elements to 
Table 4 Anti-nutritional factors of defatted hybrid hazelnut meals (dry basis)

\begin{tabular}{|c|c|c|c|c|}
\hline Genotype & $\begin{array}{l}\text { Total } \\
\text { phenolics } \\
\left(\mathrm{mg} \mathrm{TA} \mathrm{g}^{-1}\right)\end{array}$ & $\begin{array}{l}\text { Tannins } \\
\left(\mathrm{mg} \mathrm{TA} \mathrm{g}^{-1}\right)\end{array}$ & $\begin{array}{l}\text { Condensed } \\
\text { tannins (\% } \\
\text { leucocyanidin } \\
\text { equivalent) }\end{array}$ & $\begin{array}{l}\text { Phytates } \\
\left(\mathbf{m g ~ g}^{-1}\right)\end{array}$ \\
\hline $1-20$ & $12.3 \pm 1.13^{a b}$ & $8.94 \pm 0.87^{a}$ & $1.53 \pm 0.12^{a}$ & $24.7 \pm 1.20^{c d}$ \\
\hline $10-50$ & $9.30 \pm 0.56^{d}$ & $6.50 \pm 0.63^{c}$ & $0.32 \pm 0.11^{f g}$ & $25.6 \pm 1.06^{c}$ \\
\hline $10-57$ & $8.71 \pm 0.34^{d}$ & $5.56 \pm 0.30^{d}$ & $0.25 \pm 0.12^{g}$ & $33.0 \pm 0.99^{a}$ \\
\hline $11-54$ & $10.6 \pm 0.65^{c}$ & $7.80 \pm 0.75^{b}$ & $0.63 \pm 0.09^{d}$ & $31.5 \pm 1.46^{a}$ \\
\hline $13-34$ & $11.5 \pm 0.09^{b c}$ & $6.78 \pm 0.18^{c}$ & $0.26 \pm 0.05^{g}$ & $18.5 \pm 1.24^{f}$ \\
\hline $16-177$ & $12.9 \pm 0.40^{a}$ & $9.12 \pm 0.39^{a}$ & $0.83 \pm 0.04^{c}$ & $28.7 \pm 0.86^{b}$ \\
\hline $18-12$ & $9.17 \pm 0.33^{d}$ & $6.54 \pm 0.30^{c}$ & $0.51 \pm 0.02^{d e}$ & $21.5 \pm 1.38^{e}$ \\
\hline $25-60$ & $9.51 \pm 0.09^{d}$ & $6.83 \pm 0.13^{c}$ & $0.41 \pm 0.07^{e f}$ & $32.3 \pm 1.31^{a}$ \\
\hline $28-105$ & $10.8 \pm 0.40^{c}$ & $7.80 \pm 0.67^{b}$ & $0.38 \pm 0.12^{e f g}$ & $25.2 \pm 0.96^{c d}$ \\
\hline 29-142 & $12.7 \pm 0.41^{a}$ & $9.46 \pm 0.46^{a}$ & $1.28 \pm 0.04^{b}$ & $23.2 \pm 0.76^{d e}$ \\
\hline Mean & $10.7 \pm 1.54$ & $7.53 \pm 1.31$ & $0.64 \pm 0.44$ & $26.4 \pm 4.8$ \\
\hline Range & $8.71-12.9$ & $5.56-9.46$ & $0.25-1.53$ & $18.5-33.0$ \\
\hline
\end{tabular}

Data are expressed as mean of three replications.

Means followed by the same letter within a column indicate no significant $(P>0.05)$ difference by Ducan's multiple range test.

form insoluble complexes. Enujiugha (2003) found that osteomalacia developed when certain legumes and cereals rich in phytate were fed to growing animals. Additionally, phytates are known to be primary storage forms of $\mathrm{P}$, which reduce $\mathrm{P}$ bioavailability (Siddhuraju et al., 1995). In spite of some negative effects, phytate also may have possible health benefits in human nutrition, such as in the management of diabetes and obesity (Eleyinmi et al., 2008). As was found with phenolics and tannins, soaking and thermal processing effectively reduces phytate level (Enujiugha, 2003).

\section{Conclusions}

This study is one part of our ongoing investigations of value-added opportunities for Nebraska hybrid hazelnuts for food, feed and industrial applications and focus on nutritional and anti-nutritional compositions of Nebraska hybrid hazelnut-defatted meal. The meals were found to be rich in protein, carbohydrate, energy value, NDF and ADF, which make them a good source for livestock feed. Mineral concentrations in our meals were higher than previously studied Turkish ones. All essential amino acid contents in our meals were significantly $(P<0.05)$ lower than the reference levels recommended for human and animal consumption. The high levels of anti-nutritional factors may reduce protein and mineral bioavailability. Although Nebraska hybrid hazelnut-defatted meals are nutritionally incomplete, they remain a potential resource for human and animal consumption, when supplemented with some essential amino acids and when the relative concentrations in anti-nutritional factors are reduced via thermal processing. Further studies will be conducted in these fields.

\section{Acknowledgments}

Technical support from Drs. Xianghua Luo, Dan Snow, Phillip Miller, Jun Dang, and Edward Sismour, Mr. Hui Gao and Ms. Ruth Diedrichsen, is acknowledged. This research was supported, in part, by funds provided through the Hatch Act, USDA Evans-Allen and the Nebraska Department of Agriculture Specialty Crop Block Grant Programs. The article is a contribution of a joint effort between University of Nebraska-Lincoln and Virginia State University Agricultural Research.

\section{References}

Alasalvar, C., Shahidi, F., Amaral, J.S. \& Oliveira, B.P.P. (2009). Compositional characteristics and health effects of hazelnut (Corylus avellana L.): An overview. In: Tree Nuts: Composition, Phytochemicals, and Health Effects (edited by C. Alasalvar \& F. Shahidi). Pp. 185-214. Boca Raton, USA: CRC Press Taylor \& Francis Group.

AOAC. (1990). Official Methods of Analysis, vol. 2, 15th edn. Ch 40, Pp. 1-2. Washington, DC: Association of Official Analytical Chemists.

Belewu, M.A., Fagbemi, T., Dosumu, O.O. \& Adeniyi, M.O. (2008). Physico-chemical and anti-nutritional properties of some lesser known tree and leguminous seeds. International Journal of Agricultural Research, 3, 237-242.

Bonvehi, J.S. \& Coll, F.V. (1993). Study of the carbohydrate fraction of the principal varieties of Tarragona hazelnuts (Corylus avellana L.). Food Chemistry, 46, 285-288.

Buyukcapar, H.M. \& Kamalak, A. (2007). Partial replacement of fish and soybean meal protein in mirror carp (Cyprinus carpio) diets by protein in hazelnut meal. South African Journal of Animal Science, 37, 35-44.

Chivandi, E., Kachigunda, B. \& Fushai, F. (2005). A comparison of the nutrient and antinutrient composition of industrially processed Zimbabwean Jatropha curcas and Glycine max meals. Pakistan Journal of Biological Sciences, 8, 49-53.

Dini, I., Tenore, G.C. \& Dini, A. (2005). Nutritional and antinutritional composition of Kancolla seeds: an interesting and underexploited andine food plant. Food Chemistry, 92, 125-132. 
Doğan, G. \& Erdem, M. (2010). Effects of hazelnut meal levels on growth performance, feed utilization and digestibility in Juvenile Rainbow Trout (Oncorhynchus mykiss). Turkish Journal of Fisheries and Aquatic Sciences, 10, 181-186.

Eleyinmi, A.F., Sporns, P. \& Bressler, D.C. (2008). Nutrional composition of Gongronema latifolium and Vernonia amygdalina. Nutrition \& Food Science, 38, 99-109.

Emre, Y., Sevgili, H. \& Sanli, M. (2008). A preliminary study on the utilization of hazelnut meal as a substitute for fish meal in diets of European sea bass (Dicentrarchus labrax L.). Aquaculture Research, 39, 324-328.

Enujiugha, V.N. (2003). Chemical and functional characteristics of conophor nut. Pakistan Journal of Nutrition, 2, 335-338.

Enujiugha, V.N. \& Ayodele-Oni, O. (2003). Evaluation of nutrients and some anti-nutrients in lesser-known, underutilized oilseeds. International Journal of Food Science and Technology, 38, 525-528.

Erener, G., Burak, F. \& Ocak, N. (2009). A study on feeding hazelnut kernel oil meal as a protein source for broiler chickens. Animal Science Journal, 80, 305-309.

FAO/IAEA. (2000). Quantification of tannins in tree foliage. A laboratory manual for the FAO/IAEA Co-ordinated research project on "use of nuclear and related techniques to develop simple tannin assays for predicting and improving the safety and efficiency of feeding ruminants on tanniniferous tree foliage'. Available at: http://www-naweb.iaea.org/nafa/aph/public/pubd31022manual-tannin.pdf (accessed on 13 January 2011).

FAO/WHO/UNU. (1985). Energy and protein requirements in Report of a Joint FAO/WHO/UNU Expert Consultation; World Health Organization Technical Report Series 724; Geneva, Switzerland.

Francis, G., Makkar, H.P.S. \& Becker, K. (2001). Antinutritional factors presents in plant-derived alternate fish feed ingredients and their effects in fish. Aquaculture, 199, 197-227.

Hammond, E.. (2006). Identifying Superior Hybrid Hazelnut Plants in Southeast Nebraska. Masters thesis. 60 Pp. Lincoln: University of Nebraska.

Kaushik, S.J., Cravedi, J.P., Lalles, J.P., Sumpter, J., Fauconneau, B. \& Laroche, M. (1995). Partial or total replacement of fish meal by soybean protein on growth, protein utilization, potential estrogenic or antigenic effects, cholesterolemia and flesh quality in rainbow trout. Oncorhynchus mykiss. Aquaculture, 133, 257-274.

Kikuchi, K. (1999). Use of defatted soybean meal as a substitute for fish meal in diets of Japanese flounder (Paralichthys olivaceu). Aquaculture, 179, 3-11.

Köksal, A.İ., Artik, N., Şimşek, A. \& Guneş, N. (2006). Nutrient composition of hazelnut (Corylus avellana $\mathrm{L}$.) varieties cultivated in Turkey. Food Chemistry, 99, 509-515.

Latta, M. \& Eskin, M. (1980). A simple and rapid colorimetric method for phytate determination. Journal of Agricultural and Food Chemistry, 28, 1313-1315.

Makkar, H.P.S., Bluemmel, M., Borowy, N.K. \& Becker, K. (1993). Gravimetric determination of tannins and their correlations with chemical and protein precipitation methods. Journal of The Science of Food and Agriculture, 61, 161-165.
Mukhopadhyay, N., Sarkar, S. \& Bandyopadhyay, S. (2007). Effect of extrusion cooking on anti-nutritional factor tannin in linseed (Linum usitatissimum) meal. International Journal of Food Sciences and Nutrition, 58, 588-594.

Opapeju, F.O., Golian, A., Nyachoti, C.M. \& Campbell, L.D. (2006). Amino acid digestibility in dry extruded-expelled soybean meal fed to pigs and poultry. Journal of Animal Science, 84, 1130-1137.

Porter, L.J., Hrstich, L.N. \& Chan, B.G. (1986). The conversion of procyanidins and prodelphinidins to cyanidin and delphinidin. Phytochemistry, 25, 223-230.

Prieto, R.M., Fiol, M., Perello, J. et al. (2010). Effects of Mediterranean diets with low and high proportions of phytate-rich foods on the urinary phytate excretion. European Journal of Nutrition, 49, 321-326.

Segura, R., Javierre, C., Lizarraga, M.A. \& Ros, E. (2006). Other relevant components of nuts: phytosterols, folate and minerals. British Journal of Nutrition, 96 (Suppl. 2), S36-S44.

Shiau, S.Y., Lin, S.F., Yu, S.F., Lin, A.L. \& Kwok, C.C. (1990). Defatted and full-fat soybean meal as partial replacements for fishmeal in tilapia (Oreochromis niloticus X O. aureus) diets at low protein level. Aquaculture, 86, 401-407.

Siddhuraju, P., Vijayakumari, K. \& Janardhanan, K. (1995). Studies on the underexploited legumes, Indigofera linifolia and Sesbania bispinosa: nutrient composition and antinutritional factors. International Journal of Food Science and Nutrition, 46, 195-203.

Siddhuraju, P., Becker, K. \& Makkar, H.P.S. (2001). Chemical composition, protein fractionation, essential amino acid potential and antimetabolic constituents of an unconventional legume, Gila bean (Entada Phaseoloides Merrill) seed kernel. Journal of The Science of Food and Agriculture, 82, 192-202.

Simsek, A. \& Aykut, O. (2007). Evaluation of the microelement profile of Turkish hazelnut (Corylus avellana L.) varieties for human nutrition and health. International Journal of Food Sciences and Nutrition, 58, 677-688.

Van Soest, P.J. (1963). Use of detergents in the analysis of fibrous feeds. II A rapid method for the determination of fiber and lignin. Journal of the Association of Official Analytical Chemists, 46, 830.

Van Soest, P.J., Robertson, J.B. \& Lewis, B.A. (1991). Methods for dietary fiber, neutral detergent fiber and non-starch polysaccharides in relation to animal nutrition. Journal of Dairy Science, 74, 3583.

Xu, Y.X. \& Hanna, M.A. (2010a). Evaluation of Nebraska hybrid hazelnuts: nut/kernel characteristics, kernel proximate composition, and oil and protein properties. Industrial Crops Products, 31, 84-91.

Xu, Y.X. \& Hanna, M.A. (2010b). Composition and oxidative stabilities of oils extracted from hybrid hazelnuts grown in Nebraska, USA. International Journal of Food Science and Technology, 45, 2329-2336.

Xu, Y.X., Hanna, M.A. \& Josiah, S.J. (2007). Hybrid hazelnut oil characteristics and its potential oleochemical application. Industrial Crops Products, 26, 69-76.

Yalcin, S., Oĝuz, F. \& Yalcin, S. (2005). Effect of dietary hazelnut meal supplementation on the meat composition of quails. Turkish Journal of Veterinary and Animal Sciences, 29, 1285-1290. 